\title{
Skal man være feminist for at skrive kvindelitteraturhistorie?
}

Red. Anne-Marie Mai: Nordisk kvindelitteraturhistorie. Over alle grænser 1990-2015. Syddansk Universitetsforlag 2017, 294 sider, smukt illustreret. Findes dertil (gratis) på nettet - https://nordicwomensliterature.net/da/

Udgivelsen af Nordisk kvindelitteraturhistorie bind 1-5 blev egentlig afsluttet i 1998 med det særdeles praktiske forfatterleksikon "Liv og værk". I 1997 var bind 4 "På jorden", som dækker perioden 1960-1990, udkommet. Det blev afsluttet af et lille smugkig på 90'ernes debutanter, hvorfor det nye opdateringsbind altså har de seneste 25 års nordisk litteratur skrevet af kvindelige forfattere at samle op på. Det er en udfordrende opgave, som redaktøren har løst ved at kombinere seks relativt traditionelle præsentationer af periodens vægtige, nordiske romanforfattere: Helle Helle, Hanne Ørstavik, Sofi Oksanen, Sara Stridsberg, Auður Jónsdóttir og Monika Fagerholm med et efterfølgende mix af "tendensartikler" om fx adoptionslitteratur, selvfremstilling, krop og miljø, hvortil kommer kapitler om genre- og minoritetslitteratur - fx børne- og ungdomslitteratur, krimilitteratur, chicklit samt (særdeles fine) sonderinger i den grønlandske, samiske og tornedalske litteraturscene.

Man kan diskutere, som redaktøren af dette bind, Anne-Marie Mai, da også gør i bogens indledning, om prædikatet "kvindelitteratur" er et kainsmærke eller en nødvendig, politisk markering. Ebba Witt-Brattström, der har skrevet den glimrende artikel om Sofi Oksanen, er i hvert fald ikke i tvivl. Hun skriver, kvinderomanen er en litteraturform:

46

[...] som altid er på kvindernes side, som skildrer kvindekønnets væren i verden som afgørende, tager kvinders kvaler dybt alvorligt i stedet for at banalisere dem, vasker offerstemplet af kvinden og gør hende til aktør i historien og i sin skæbne, "degraderer" manden til menneske i stedet for norm, kritiserer mænds undertrykkelse af kvinder og deres kvindeforagtende adfærd - og, væsentligt: giver kvindekroppen en stemme, så fortrængte, socialt tabuiserede erfaringer kommer til udtryk. (s. 42)

Det er et klart og utvetydigt feministisk udsagn, som man efter endt læsning af værket glæder sig over, at Brattström ikke har tøvet med at fremføre. Hvorfor skal vi vende tilbage til, men først lidt om grundene til at Over alle grænser, ligesom alle de tidligere bind i Nordisk Kvindelitteraturhistorie, demonstrerer sin egen uimodsigelige nødvendighed. De kvindelige forfattere, som bogen behandler, skal ikke fiskes frem fra glemte arkiver. Det kræver naturligvis ikke et arkæologisk grundforskningsarbejde at få øje på, at Sara 
Stridsberg, Sofi Oksanen, Maja Lee Langvad eller Athena Farrokhzad er centrale stemmer i tiden. Det arbejde, som kønsforskeren af i dag har at gøre, må være et andet nemlig at fremhæve kønsdimensionen i disse forfatterskaber. Samtalen om kønnets betydning er bestemt ikke slut. Vi lever stadig under en patriarkalsk orden, hvis nogen da ellers skulle være i tvivl, og det betyder, at emner, der vedrører kvinders historie, krop, seksualitet og følelsesliv, stadig betragtes som mindre væsentlige litterære temaer. I en dansk kontekst er det vist tilstrækkeligt at nævne diskrepansen mellem kritikkens ubetingede hyldest af Karl Ove Knausgårds maskulinitetesudforskende hverdagsskildringer, og det raseri, der er blevet rettet mod kvindelige forfattere, som har tematisereret lesbisk seksualitet, racialisering eller spiseforstyrrelser. Knausgårds erfaringer vedkommer åbenbart "alle", mens Maja Lee Langvads udtrykker en "særidentitet". Der er med andre ord lang vej endnu, og af og til er man ikke engang sikker på, at vejen overhovedet går fremad. Igen og igen må undertegnede efterlyse litteratur skrevet af kvinder på universiteternes litteraturkurser. Også derfor er Over alle grænser en vigtig bog. Den er simpelthen med til at fastholde og suverænt demonstrere, at kønsperspektivet stadig er absolut aktuelt.

Der er mange gode enkelttekster i bogen, og jeg kan ikke omtale dem alle. Foruden Brattströms Oksanen-læsning skal Lilian Munk Rösings skarpe læsning af Stridsberg, Pia Ingströms gode sammenfatning af motiverne hos Monika Fagerholm, og Iben Engelhardts nuancerede omgang med migrations-og adoptionsperspektivet fremhæves. Kirsten Thisteds artikel om grønlandsk litteratur og Anne Heiths om samisk og tornedalsk litteratur er simpelthen must-reads. Det er vederkvægende, at de nordiske minoritetslitteraturer bliver behandlet så kyndigt og så interessant, og artiklerne om genrelitteratur er generelt fine, endskønt en væsentlig genre desværre savnes: den grafiske roman. I Nina Christensens og Mia Österlunds kapitel om børne- og ungdomslitteratur nævnes et par af de væsentlige svenske serieforfattere, men i forhold til genrens udbredelse, dens vilde og fornyende værker og helt centrale placering i arbejdet med at beskrive og fortolke kønnet er det en dum underprioritering. Hvis man ikke har læst Kvinnor ritar bara serier om mens (red. Sara Olausson og Frida Ulvegren), er man faktisk gået glip af noget væsentligt, hvortil kommer, at en diskussion af såkaldt mummy porn ville have klædt Charlotte Jørgensens chicklit-artikel. Og nu vi er ved undladelsessynderne. Hvor i alverden er de tre største og væsentligste kvindelige digtere, der er kommet frem i præcis den periode, som bogen dækker, blevet af? Jeg tænker naturligvis på Jenny Tunedal, Kristin Berget og Ursula Andkjær Olsen. Jeg har noget svært ved at forstå, hvordan de kan være smuttet igennem nettet, og det hjælper ikke på min forståelse, at andre forfattere dukker op med en særdeles høj frekvens. Jeg skal være den sidste til at anfægte, at Athena Farrokhzad er en betydningsfuld forfatter, men hun omtales og citeres altså også i hele tre af bogens artikler, og for Christina Hagens vedkommende er det fire. Jeg vil faktisk anbefale redaktionen at supplere netudgaven med omtaler af ovennævnte, og så mærkværdigt udeladte, forfattere. Det er helt forståeligt, at bogen, som Anne-Marie Mai indledningsvis formulerer det, "desværre ikke har plads til at få alle vigtige og betydningsfulde forfattere omtalt" (s. 19) - men i det her tilfælde kan der næppe være tale om et bevidst fravalg. Den nordiske fordeling er heller ikke $100 \%$ i balance, specielt i forhold til den norske litteratur, hvor Tone Hødnebø og Vigdis Hjorth også er savnede. Og der er, må det også siges, en vis overrepræsentation af danske skribenter (50\%). 
Og lad mig så vende tilbage til den feministiske definition af kvinderomanen, som Brattström bringer på banen. For Brattström skal den "vaske offerstemplet af kvinden og gøre hende til aktør i historien og i sin skæbne”, og den skal “'degradere’ manden til menneske i stedet for norm”. Dette er det feministisk bevidste subjekts, og, vil jeg tilføje, den feministiske litteraturhistorieskrivers, selvfølgelige udgangspunkt. Hvordan litteraturen så gestalter denne anti-androcentriske, kritiske bevægelse (i hvilke genrer, i hvilke former) eller undertrykkelsen af den, er for så vidt mindre væsentligt. Men hvis man skriver kvindelitteraturhistorie uden at have gjort sig det normativitetskritiske udgangspunkt klart, så kan man komme til at gentage og befæste de fordomme, som litteratur skrevet af kvinder sådan set altid er blevet mødt af. Når Per Krogh Hansen skriver sådan her om Helle Helles forfatterskab: "Men er der tale om tidsbilleder, som receptionen af hende har hævdet? Måske i detaljerne, men ikke generelt. Den omkringliggende virkelighed - den politiske og historiske - er så godt som fraværende i teksterne" (s. 21), og konkluderer, at "det i mindre grad er billeder af nutidens kvinder, Helle har givet os, end det er en tematisering af almenmenneskelige eksistentialer, udtrykt gennem kvindelige karakterer" (s. 30), så må denne feministiske killjoy straks både spørge til, hvorfor såkaldte "detaljer" ikke siger noget om "historien", og hvem det egentlig er, der definerer beskaffenheden af de "almenmenneskelige eksistentialer", som de kvindelige karakterer formodes at være tilfældige hylstre for. Helle Helles forfatterskab har efterladt mange billeder hos denne læser: ét af dem er et billede af en kvinde, som hurtigt kører noget shampoo rundt i en snavset håndvask, fordi det ringer på døren - det er vel en eksistentiel erfaring - men er den historieløs og almenmenneskelig?

Skal man med andre ord være feminist for at skrive kvindelitteraturhistorie? Selvfølgelig skal man det. At skrive specifikt om kvindelige forfattere giver simpelthen ikke mening i en kvindelitteraturhistorisk kontekst, hvis man gør det uden at have taget kønsteoretisk stilling til de valg, denne kategorisering også indebærer. Et kategoriseringsvalg som Mara Lee andetsteds i bogen citeres for at kalde "en mulighed, vi ikke bare skal frasige os" (s. 12). Og det er jeg enig med Mara Lee i. Det giver rigtig god mening at samle op på de tematikker og former, der strømmer gennem den samtidslitteratur, der på en eller anden måde forholder sig til køn og andre forskelle - og som er skrevet af kvinder - af alle køn. Det sidste tilføjer jeg både for at drille lidt og samtidig for at markere min positive holdning til bogens titel: Over alle grænser. Uanset hvad reaktionære kritikere, der beskylder såkaldt "identitetspolitisk" litteratur (er der nogen, der kan levere en positiv definition af dén kategori - nej vel?) for at være ekskluderende og sågar destruktiv for det demokratiske projekt, måtte mene, er det fuldt ud muligt at fastholde kønnet som forbundet med sine historiske og diskursive repræsentationer (dét skal vi stadig arbejde med) og på samme tid fastholde, at den individuelle kønsidentitet kan være så mangfoldig som havets sand og himlens stjerner (det skal vi også arbejde med). Begge aspekter af kønnet sidder dertil fast i specifikke kroppe, der gennemkrydses af deres historie og det pres, der udøves af repræsentationerne - såvel som af de uendeligt mange forskelle, der findes i hiin enkelte.

Og dette intensive krydsfelt, som er kønnets, præsenteres generelt på fornem vis i Over alle grænser, hvis nordiske udgangspunkt virkelig også må påskønnes. Man bliver simpelthen glad af at konstatere, hvor levende, udfordrende - og bomstærkt - der skrives af kvinder i Norden i dag. Over alle grænser åbner utrolig mange døre til forfattere og pro- 
blematikker, som vil være nye og spændende bekendtskaber for rigtig mange læsere. Så mange tak for den. Og så et lille suk: I en tid hvor kønsforskningen i Danmark i dén grad er under pres - jf. den forestående lukning af KVINFOs bibliotek, KVINFO som har været primus motor i udgivelsen af hele værket Nordisk Kvindelitteraturhistorie, og de enorme skadevirkninger som denne lukning vil komme til at få - kan Over alle grænser også tjene som en aktuel påmindelse om, hvorfor kvindehistorie er alles historie, og hvad vi går glip af, hvis vi holder op med at skrive den.

Anmeldt af Elisabeth Friis

\section{Knausgårds udfordring}

Claus Elholm Andersen (red.) Så tæt på livet som muligt: Perspektiver på Karl Ove Knausgårds Min kamp. Hellerup og Bergen: Spring / Alvheim \& Eide Akademisk Forlag, 2017, 248,00 kr., 286 sider.

Da jeg hørte, at der var kommet en litteraturvidenskabelig antologi om Karl Ove Knausgårds Min kamp, blev jeg begejstret. For lige siden Knausgårds bog udkom, har jeg ment, at dette værk er en grundlæggende udfordring for litteraturvidenskaben. Med Claus Elholm Andersens udgivelse af Så tæt på livet som muligt, en samling med 13 bidrag af litteraturforskere som tilsammen repræsenterer otte lande og tre generationer (den yngste bidragyder er under 30, den ældste et godt stykke over 70), får vi endelig en mulighed for at se, hvordan litteraturforskere tager Knausgårds handske op.

Jeg læste antologien med stor spænding og fik meget ud af den. Ikke fordi bogen indeholder en endelig afklaring af, hvad Min kamp er, hvor den står i litteraturhistorien, eller hvordan den forholder sig til dagens litteraturteori, og heller ikke fordi alle bidragene er lige gode, men fordi den gav mig et førstehåndsindtryk af, hvad litteraturforskere hæfter sig ved i Knausgårds storværk.

Antologien viser, at vi litteraturforskere stort set læser ud fra de synsvinkler og teorier, vi til hverdag arbejder med. Andet ville jo også bare lede til totalt uautentiske læsninger. Hvis jeg er dybt fascineret af Genettes narratologi, vil jeg uvægerligt læse med dens kategorier in mente og mobilisere dem, når jeg synes, de tilføjer noget til læsningen. Fordi Min kamp handler om alt, hvad der findes i et almindeligt menneskeliv, samtidig med at værket også handler om skrivning, litteratur, kunst og eksistens, giver teksten fodfæste for utroligt mange forskellige teoretiske synsvinkler.

Inge van de Ven udforsker Min kamps forhold til sociale medier og "big data". Selvom emnet kan virke søgt (for hvad har en så eksistentiel tekst med databaser at gøre?), viser van de Ven, at det faktisk er interessant at diskutere forholdet mellem "databasernes uafsluttethed” og Knausgårds omfattende brug af lister. Og heldigvis indrømmer hun villigt, at Knausgårds roman har mere tilfælles med Proust end med en database. De mest interessante dele af Stefan Kjerkegaards essay griber fat i Knausgårds oplevelse af det sociale 